\title{
Color Comparison between Korean and Foreign-made Base Makeup Products
}

\author{
In Jung ${ }^{1,2}$, In-Sook $\mathrm{An}^{2}$, Sungkwan $\mathrm{An}^{3 *}$ \\ ${ }^{1}$ Department of Biological Engineering, Konkuk University, Seoul, Korea \\ ${ }^{2}$ Korea Institute of Dermatological Sciences, Seoul, Korea \\ ${ }^{3}$ Department of Cosmetics Engineering, Konkuk University, Seoul, Korea
} \begin{abstract}
Gwangjin-gu, Seoul 05029, Korea
Tel.: +82 24504054

Fax: +82 5027702278

Email: ansungkwan@konkuk.ac.kr

Received January 30, 2018

Revised February 22, 2018

Accepted February 28, 2018

Published June 30, 2018
\end{abstract}

*Corresponding author: Sungkwan An, Department of Cosmetics Engineering, Konkuk University, 120 Neungdong-ro,

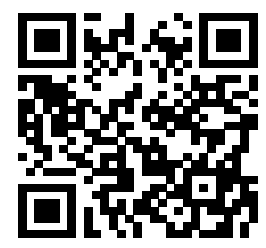

\begin{abstract}
Purpose: This study aimed to investigate the complexion preference of Korean women by comparing the colors of Korean and foreign-made base makeup products. Methods: A square test area measuring $2 \times 2 \mathrm{~cm}$ was marked on a Bioskin plate for comparison of "before" and "after" measurements. The before data were measured using a spectrophotometer in triplicate at the same position to take into account any deviation. $L^{*} a^{*} b^{*}$ values for Korean and foreign-made products were measured, and the mean and standard deviation were calculated and compared for significance. Results: The $\mathrm{L}^{*}$ improvement rates of the Korean products were higher than those of foreign-made products (23.5\% versus $9.1 \%)$, and the $a^{*}$ improvement rates of the Korean products were also higher (27.2\% versus $23.0 \%$ ), but the $b^{*}$ improvement rates of the Korean products were lower than those of the foreign-made products (17.3\% versus $32.3 \%)$. Conclusion: Korean products better reflect Korean consumers' preference for toning up. The imported products featured a transparent and natural color development. Traditionally, European companies have focused on the needs of people with whiter skin than Asians, and therefore, the imported products might be toned to mask yellow complexions as much as possible and develop bluish tones.
\end{abstract}

Keywords: Skin color, Face, Korean women, Base makeup, BB cream

\section{Introduction}

The earliest evidence for the use of makeup by humans comes from clam shells found in the southern Spanish region of Murcia. In these shells, a putative cosmetic substance that was apparently used as a foundation was found, consisting of a red powder mixed with a yellow pigment and a black mineral. This may be the first evidence that 50,000 years ago, Neanderthals made makeup using pigments and applied it to decorate themselves supporting the claim that they used fire, made stoneware, had a culture surrounding burial, and were a race of considerable intelligence (Zilhão et al., 2010).

The period over which human beings have used makeup is thus very long, and although the purpose of makeup has varied, its use in modern times is now fairly consistent. Base makeup refers to products that cover defects and flaws in the skin, such as freckles, while also changing the skin color according to the user's taste, giving gloss, elasticity, and transparency to the skin (Lee, 2005). While base makeup products are applied to the entire facial skin surface, point makeup products serve to highlight a specific area (Fabricant \& Gould, 1993; quoted in Kim et al., 2004).

A product in use today, created by a German dermatologist was originally produced as a skin protection ointment to calm and cover the red spots that accompanied the peeling procedure used in hospitals to treat patients 
had skin problems. This product, at first used only in hospitals was eventually released as a general cosmetic in 1960, and official imports to Korea began in 1983. However, in 2006, a Korean cosmetics company launched its own version of this "blemish balm" (BB) cream which became more famous than the original product, proving an unprecedented success (Kim et al., 2011; Kim \& Jeong, 2011). BB cream is a newly reinterpreted product in Korea; in a survey (Park \& Chin, 2010), only 2.3\% of 360 people knew exactly what the initials BB stood for, whereas $45.7 \%$ did not.

Sahay \& Piran (1997) reported that South AsianCanadian female university students have strong desire to want light skin color than European-Canadian female university students, and moreover Kowner (2004) reported that Japanese women answered they want brighter skin, either. Thus, one effect of base makeup products is that they impart and change a color to the skin. Although there have been studies measuring color in the fashion industry, there has been little research to measure or compare the color of base makeup products. This study investigated color (using $\mathrm{L}^{*} \mathrm{a}^{*} \mathrm{~b}^{*}$ values) and improvement rates for some Korean and foreign-made base makeup products. In addition, we will analyze how well the existing toning colors appeal to Korean women by comparing the colors of the Korean products and foreignmade products with that of the $\mathrm{BB}$ cream already sold in the Korean market.

\section{Methods}

\section{Instruments and materials}

Urethane elastomer-based artificial skin (Bioskin plate \#30; Beaulax, Japan) was used as a skin model. This model mimics the texture and elasticity of human skin and may be measured easily with a spectrophotometer. It is available in a plate form, in eight different skin colors, and is used not only for evaluating basic cosmetics, makeup products, and cleansers, but also for presenting objective data in applying for cosmetics-related patents (Nonomura \& Yamaguchi, 2016).

A spectrophotometer (CM-2600d; Konica Minolta, Japan) was used to measure Bioskin plate $\mathrm{L}^{*} \mathrm{a}^{*} \mathrm{~b}^{*}$ values.
SpectraMagic NX (CM-S100w; Konica Minolta, Japan) software was used to record measurements and provide a more comprehensive color analysis (Kim \& Choi, 2018; Nakamura, 1998; Weatherall \& Coombs, 1992; Yun et al., 2010).

A four-sided film applicator (SH1107/80/1; Sheen Instruments, UK) with gap sizes of 30, 60, 90, and 120 $\mu \mathrm{m}$ was used to evenly apply BB cream on a Bioskin plate to the required application thickness. In general, the use of brushes, puffs, sponges, and so forth to apply makeup is unsatisfactory for research because of the variation in the user's touch and force applied, whereas the foursided applicator in combination with the flat Bioskin plate reliably produced uniform coatings of the product (Kim \& Park, 2013).

Product sample weight was measured with a digital electronic scale (EK-410i; A\&D, Korea) to a resolution of $0.01 \mathrm{~g}$.

\section{Research product selection criteria}

Eight different Korean and foreign-made BB cream products were selected and purchased in order to investigate which most closely matched the preference of Korean women for skin tone coloring.

The selection criteria for the products were as follows. First, as of January 2, 2018, the product had to be routinely produced or imported into Korea and could be freely purchased in retail situations. Second, the product's name had to include the initials "BB" so that the consumer could accurately identify it as BB cream, and the initials "BB" had to be clearly printed on the packaging and container. Third, to avoid testing BB creams produced by the same manufacturer under a different brand name, each cream had to be produced by a different manufacturer. Fourth, the product had to be available in only a single color (i.e., consumers had no choice of color) and classified under a single stock keeping unit to ensure that no other product existed with the same product name. Fifth, for the comparison between countries, four of those selected were produced in Korea and the remaining four were imported from Europe.

Tables 1 and 2 show product information, including ingredients, manufacturer, and manufacturer's address. Korean products are designated with a "K" and displayed 
Table 1. Ingredients of Korean BB cream

\begin{tabular}{|c|c|c|}
\hline Products & Ingredients & Manufacturer and address \\
\hline K\#1 & $\begin{array}{l}\text { Water, Ethylhexyl methoxycinnamate, Isododecane, Ethylhexyl salicylate, Phenethyl } \\
\text { benzoate, Titanium dioxide, Dipropylene glycol, Phenylbenzimidazole sulfonic acid, PEG- } \\
30 \text { Dipolyhydroxystearate, Niacinamide, Glycerin, Cyclopentasiloxane, Tromethamine, } \\
\text { Polyglyceryl-3 polyricinoleate, Disteardimonium hectorite, 1,2-Hexanediol, Pinus } \\
\text { pinaster bark/bud extract, Diethylamino hydroxybenzoyl hexyl benzoate, Lauryl PEG-9 } \\
\text { polydimethylsiloxyethyl dimethicone, Bis-ethylhexyloxyphenol methoxyphenyl triazine, } \\
\text { Hydrogenated polyisobutene, Zinc stearate, Dimethicone, Aluminum hydroxide, } \\
\text { Sorbitan sesquioleate, Polyglyceryl-6 polyricinoleate, Stearic acid, Magnesium sulfate, } \\
\text { Cetyl PEG/PPG-10/1 dimethicone, Palmitoyl proline, Adenosine, Magnesium palmitoyl } \\
\text { glutamate, Sodium palmitoyl sarcosinate, Triethoxycaprylylsilane, Palmitic acid, } \\
\text { Distearyldimonium chloride, Fragrance, Titanium dioxide (Ci 77891), Mica, Iron oxides } \\
\text { (Ci 77492), Iron oxides (Ci 77491) }\end{array}$ & $\begin{array}{l}\text { LG Household \& Health Care. } \\
58 \text { Saemunan-Ro, Jongro-Gu, } \\
\text { Seoul, Korea }\end{array}$ \\
\hline K\#2 & $\begin{array}{l}\text { Water, Cyclopentasiloxane, Titanium dioxide, Glycerin, Butylene glycol, Talc, Ethylhexyl } \\
\text { methoxycinnamate, PEG-10 dimethicone, Hexyldecyl myristoyl Methylaminopropionate, } \\
\text { Dimethicone/vinyl dimethicone crosspolymer, Cyclomethicone, Prunus amygdalus } \\
\text { dulcis (sweet almond) Oil, Isopropyl isostearate, Zinc oxide, Disteardimonium hectorite, } \\
\text { Betaine, Triethylhexanoin, Portulaca oleracea extract, Tocopheryl acetate, Candida } \\
\text { bombicola/glucose/methyl rapeseedate ferment, Melaleuca alternifolia (Tea tree) } \\
\text { Leaf oil, Rubus idaeus (Raspberry) fruit extract, Chaenomeles sinensis fruit extract, } \\
\text { Schizandra chinensis fruit extract, Actinidia chinensis (Kiwi) fruit extract, Magnesium } \\
\text { sulfate, Vinyl dimethicone/methicone silsesquioxane crosspolymer, Acrylates/ } \\
\text { dimethicone copolymer, Methicone, Glycosyl trehalose, Palmitic acid, Hydrogenated } \\
\text { starch hydrolysate, Aluminum hydroxide, Aluminum stearate, Dimethicone, Fragrance, } \\
\text { Phenoxyethanol, Methylparaben, Propylparaben, Butylparaben, Iron oxides (Ci77492), } \\
\text { Iron oxides (Ci77499), Iron oxides (Ci77491) }\end{array}$ & $\begin{array}{l}\text { Kolmar Korea. } \\
\text { 22-17 Sandan-Gil, Jeonui- } \\
\text { Myeon, Sejong, Korea }\end{array}$ \\
\hline
\end{tabular}

Water, Cyclopentasiloxane, Titanium dioxide (Ci 77891), Butylene glycol, Butylene glycol dicaprylate/dicaprate, Dimethicone, Cyclohexasiloxane, Cetyl PEG/PPG-10/1 Dimethicone, Orbignya oleifera seed oil, Arbutin, Magnesium sulfate, Zinc oxide, Glyerin, PEG-9 Polydimethylsiloxyethyl dimethicone, Dipropylene glycol, Polyglutamic Acid, Talc, Sodium Hyaluronate, Zea mays (Corn) kernel extract, Palmitoyl tripeptide-1, Butyrospermum parkii (shea) butter, Disteardimonium hectorite, Calcium stearate, Dimethicone/vinyl dimethicone crosspolymer, Beeswax, Ozokerite, Sorbitan olivate, Sorbitan isostearate, Silica, Triethyl citrate, Triethoxycaprylylsilane, Hydrogen dimethicone, Adenosine, Hydrogenated lecithin, Disodium EDTA, Phenoxyethanol, Propylparaben, Methylparaben, Ci 77491, Ci 77492, Ci 77499

Cosmecca Korea Co., Ltd. 17-12, Daegeum-Ro 196 BeonGil, Daeso-Myeon, EumseongGun, Korea

Water, Butylene glycol, Caprylic/capric triglyceride, Phenyl trimethicone, Zinc oxide, Polyglyceryl-2 dipolyhydroxystearate, Titanium dioxide, Methyl trimethicone, Dicaprylyl carbonate, Cetyl ethylhexanoate, Sorbitan isostearate, Panthenol, Boron nitride, Disteardimonium hectorite, Polyglyceryl-3 disostearate, Glyceryl caprylate, Disodium EDTA, Sodium chloride, Stearic acid, Alumina, Aluminum hydroxide, Ethylhexylglycerin, Triethoxycaprylylsilane, Chamaecyparis obtusa leaf extract, Titanium dioxide (Ci 77891), Iron oxides (Ci 77492), Iron oxides (Ci 77491), Iron oxides (Ci 77499)

Amorepacific corporation. 100, Hangang-Daero, YongsanGu, Seoul, Korea

It copied as same with product information, including ingredients, manufacturer, and manufacturer's address on the packaging and container. A few notations of ingredients may have different from others, because it deliberately did not unify the contents to avoid distortion. Korean products are designated with a " $\mathrm{K}$ " and displayed in the order $\mathrm{K} \# 1, \mathrm{~K} \# 2, \mathrm{K \# 3}$, and $\mathrm{K} \# 4$.

in the order $\mathrm{K} \# 1, \mathrm{~K} \# 2, \mathrm{~K} \# 3$, and $\mathrm{K} \# 4$, and foreign-made products are designated with an "F" and displayed in the order F\#1, F\#2, F\#3, and F\#4.

\section{Measurement method}

In this study, Bioskin plate \#30 was used, as this was the closest to Asians' skin color. After each use, the Bioskin plate was cleaned with the same cleansing cream and foaming cleanser and then allowed to dry completely.
A square test area measuring $2 \times 2 \mathrm{~cm}$ was marked on the Bioskin plate so that before and after measurements could be made at the same location (Shimizu \& Nonomura, 2018; Sato et al., 2016). The shade of the untreated Bioskin plate was measured in the same position with a spectrophotometer to record the base readings for later comparison against treatments.

For each BB cream, $2 \mathrm{~g}$ was placed inside the marked test square on the immobilized Bioskin plate, and the 
Table 2. Ingredients of foreign-made BB cream

\begin{tabular}{ll}
\hline Products & Ingredients \\
& Aqua (water), Glycine soja (soybean) oil, Titanium dioxide, Isopropyl palmitate, Talc, \\
& Propylene glycol, Prunus amygdalus dulcis (sweet almond) oil, Cera alba, Zinc oxide, \\
& Cetyl PEG/PPG-10/1 dimethicone, Triticum vulgare (wheat) Germ oil, Zea mays (corn) \\
& Germ oil, C12-15 alkyl benzoate, Panthenol, Butyrospermum parkii (shea) butter, \\
& Tocopheryl acetate, Polyglyceryl-3 diisostearate, Dimethicone, Argania spinosa (argan) \\
& Kernel oil, Acacia seyal gum extract, Ceramide NP, Glycyrrhiza glabra (licorice) root \\
& extract, Lecithin, Phytosterols, Allantoin, Bisabolol, Helianthus annuus (sunflower) seed \\
& Oileuropaea (olive) fruit oil, Simmondsia chinensis (jojoba) seed oil, Beta-carotene, \\
& Ascorbyl palmitate, Tocopherol, Ethylhexylglycerin, Glyceryl oleate, Glyceryl stearate, \\
& Phenethyl alcohol, Sodium chloride, Sorbitol, Citric acid, Sodium hydroxide, Benzoic \\
& acid, Dehydroacetic acid, Phenoxyethanol, Potassium sorbate, Parfum (fragrance), Ci \\
& 77491, Ci 77492, Ci 77499
\end{tabular}

Manufacturer and address

\begin{abstract}
Aqua/water, Glycerin, Caprylic/Capric triglyceride, Olus oil/vegetable oil, Octyldodecanol, Rosa damascena flower water, Helianthus annuus (sunflower) seed oil, Silica, Coco-glucoside, Cetearyl alcohol, Butyrospermum parkii (shea) butter, Rosa rubiginosa seed oil, Simmondsia chinensis (jojoba) seed oil, Rosa canina flower extract, Rosa damascena flower oil, Yogurt powder, Inulin, Polyhydroxystearic acid, F\#2 Lauroyl Lysine, Alumina, Mica, Polyglyceryl-2 caprate, Levulinic acid, Coconut alcohol, Sodium gluconate, Oleic/linoleic/linolenic polyglycerides, Sclerotium gum, Xanthan gum, Sodium levulinate, Stearic acid, Sucrose stearate, Tocopherol, Squalane, Glyceryl caprylate, Biosaccharide gum-1, Parfum/fragrance, Sodium benzoate, Potassium sorbate, Geraniol, Citronellol, Linalool, Citral, Limonene, Ci 77492/iron oxides, Ci 77491/iron oxides, Ci 77499/iron oxides
\end{abstract}

Alex Cosmetic Germany Gmbh. Am Lichtbogen 38, 45141

Essen, Germany

Laboratoires M\&L. Michelet, 07150 Lagorce, France

Aqua/water, Ethylhexyl methoxycinnamate, Propylene glycol, Glycerin, Cyclopentasiloxane, Terephthalylidene dicamphor sulfonic acid, Titanium dioxide [Nano]/titanium dioxide, Drometrizole trisiloxane, Alcohol denat., Triethanolamine, Stearic acid, Potassium cetyl phosphate, Zea mays extract/corn kernel extract, Tocopherol, Sodium cocoyl sarcosinate, Hydroxypropyl tetrahydropyrantriol, Phenoxyethanol, PEG-100 stearate, Ethylparaben, Palmitic acid, Polysorbate 80, Dimethicone, Limonene, Xanthan gum, Linalool, Benzyl alcohol, Tromethamine, Isohexadecane, 3-0-Ethyl ascorbic acid, Caprylyl glycol, Carbomer, Parfum/fragrance, Acrylamide/sodium acryloyldimethyltaurate copolymer, Disodium EDTA, Jasminum officinale extract/jasmine flower extract, Cetyl alcohol, Methylparaben, Aluminum hydroxide, Glyceryl stearate [+/- May contain, Ci 77891/Titanium dioxide, Ci 77491, Ci 77492, Ci 77499/Iron oxides]

Water/aqua/eau, Homosalate, Ethylhexyl salicylate, Butyloctyl salicylate, Neopentyl glycol diheptanoate, Butyl methoxydibenzoylmethane, Benzophenone-3 (oxybenzone), Aleurites moluccana (kukui) Seed oil, Octocrylene, Lauryl PEG-9 polydimethylsiloxyethyl dimethicone, PEG-100 stearate, Butylene glycol, Methyl trimethicone, Glyceryl stearate, Dipentaerythrityl tri-polyhydroxystearate, Potassium cetyl phosphate, Glycyrrhiza glabra (licorice) root extract, Cucumis sativus (cucumber) Fruit extract, Hordeum vulgare (barley) extract/extrait D'Orge, Whey protein/lactis protein/proteine du petit-lait, Scutellaria baicalensis root extract, Laminaria ochroleuca extract, Caffeine, Cholesterol, Algae extract, Yeast polysaccharides, Propylene glycol dicaprate, Yeast extract/faex/extrait de levure, Helianthus annuus (sunflower) seedcake, Oryzanol, Sorbitol, Ethylhexylglycerin, Caprylic/capric triglyceride, Caprylyl glycol, Cetyl alcohol, Stearic acid, Tetrahexyldecyl ascorbate, Vp/eicosene copolymer, Saccharide isomerate, Dehydroxanthan gum, Sodium hyaluronate, Lecithin, Ammonium acryloyldimethyltaurate/vp copolymer, Potassium sorbate, Fragrance (parfum), Tocopheryl acetate, Citric acid, Silica, Disodium EDTA, BHT, Phenoxyethanol, [+/- Iron oxides (Ci 77491), Iron oxides (Ci 77492), Iron oxides (Ci 77499), Titanium dioxide (Ci 77891)] <In42597>

\section{Sicos And Company.}

Avenue Henri Lefebvre, 59540

Caudry, France
Estée Lauder N.V.

Nijverheidsstraat 15, 2260

Oevel, Belgium

It copied as same with product information, including ingredients, manufacturer, and manufacturer's address on the packaging and container. A few notations of ingredients may have different from others, because it deliberately did not unify the contents to avoid distortion. Foreignmade products are designated with an "F" and displayed in the order F\#1, F\#2, F\#3, and F\#4.

four-sided film applicator set at $30 \mu \mathrm{m}$ thickness.

One researcher, using the same force each time, drew the applicator over the plate to cover the test square (the measurement position) with a layer of BB cream. 
Spectrophotometer readings were then taken in triplicate for each cream, the readings were averaged, and the standard deviation was calculated. Comparison of $\mathrm{L}^{*} \mathrm{a}^{*} \mathrm{~b}^{*}$ values of Korean and foreign-made products was analyzed for significant differences.

\section{Instrumental analysis method}

When comparing BB creams between countries, it was considered that the higher the $L^{*}$ value, the better the effect of brightening the skin tone. We also predicted that a BB cream with low negative $a^{*}$ values would be beneficial for covering redness of the skin and that a cream with low negative $b^{*}$ values would disguise yellow facial shades and give skin a healthy appearance. For the analysis of the measurements of skin appearance, the paired-sample $t$-test was used. Improvement rates were calculated using the following formula:

Improvement rates $(\%)=\frac{(\text { After }- \text { Before })}{\text { Before }} \times 100$

\section{Data analysis method}

SPSS, version 18.0 (SPSS Inc., USA) was used after data coding for data processing, and results were considered significant at $p<0.05$.

\section{Results}

\section{1. $L^{*} a^{*} b^{*}$ values and improvement rates among Korean products}

The $L^{*}$ (effectiveness in lightness) values for the four Korean products weremeasured and the improvement rates were $27.2 \%$ for $\mathrm{K} \# 1,18.9 \%$ for $\mathrm{K} \# 2,19.1 \%$ for $\mathrm{K} \# 3$, and $28.6 \%$ for K\#4. The $L^{*}$ values were all significantly higher than those of the untreated Bioskin plate $(p=0.003)$. The improvement rates of $\mathrm{a}^{*}$ values (effectiveness in covering redness) were $34.6 \%$ for $K \# 1,37.4 \%$ for $K \# 2$, $26.7 \%$ for $\mathrm{K \# 3}$, and $9.7 \%$ for $\mathrm{K \# 4}$. The a values were all significantly higher than those of the untreated Bioskin plate $(p=0.023)$. The improvement rates of $b^{*}$ values (effectiveness in covering yellowness) were $12.1 \%$ for $\mathrm{K} \# 1$, $32.4 \%$ for $\mathrm{K} \# 2$, $15.0 \%$ for $\mathrm{K} \# 3$, and $9.4 \%$ for $\mathrm{K} \# 4$. The $\mathrm{b}^{*}$ values were all significantly higher than those of the untreated Bioskin plate ( $p=0.047$; Table 3$)$.

\section{2. $L^{*} a^{*} b^{*}$ values and improvement rates among Foreign- made products}

The $L^{*}$ values for the four foreign-made products were measured and improvement rates were $5.1 \%$ for $\mathrm{F} \# 1$, $5.8 \%$ for $\mathrm{F} \# 2$, $11.6 \%$ for $\mathrm{F} \# 3$, and $13.7 \%$ for $\mathrm{F} \# 4$. The

$\mathrm{L}^{*}$ values were all significantly higher than those of the

Table 3. $L^{*} a^{*} b^{*}$ values and improvement rates of Korean products

\begin{tabular}{|c|c|c|c|c|c|c|c|c|}
\hline & \multicolumn{2}{|c|}{$\mathrm{K} \# 1$} & \multicolumn{2}{|c|}{$\mathrm{K} \# 2$} & \multicolumn{2}{|c|}{ K\#3 } & \multicolumn{2}{|c|}{$\mathrm{K} \# 4$} \\
\hline & Before & After & Before & After & Before & After & Before & After \\
\hline$L^{*}$ & $58.90 \pm 0.02$ & $74.90 \pm 0.06^{* *}$ & $58.38 \pm 0.02$ & $69.44 \pm 0.05^{* *}$ & $58.69 \pm 0.02$ & $69.89 \pm 0.04^{* *}$ & $58.51 \pm 0.02$ & $75.24 \pm 0.05^{* *}$ \\
\hline $\begin{array}{l}\text { Improvement } \\
\text { rates (\%) }\end{array}$ & \multicolumn{2}{|c|}{27.2} & \multicolumn{2}{|c|}{18.9} & \multicolumn{2}{|c|}{19.1} & \multicolumn{2}{|c|}{28.6} \\
\hline$t(p)$ & \multicolumn{8}{|c|}{$-9.051(0.003)$} \\
\hline$a^{*}$ & $13.06 \pm 0.01$ & $8.54 \pm 0.04^{*}$ & $13.57 \pm 0.01$ & $8.49 \pm 0.01^{*}$ & $13.72 \pm 0.02$ & $10.06 \pm 0.05^{*}$ & $13.06 \pm 0.01$ & $11.79 \pm 0.02^{*}$ \\
\hline $\begin{array}{l}\text { Improvement } \\
\text { rates (\%) }\end{array}$ & \multicolumn{2}{|c|}{34.6} & \multicolumn{2}{|c|}{37.4} & \multicolumn{2}{|c|}{26.7} & \multicolumn{2}{|c|}{9.7} \\
\hline$t(p)$ & \multicolumn{8}{|c|}{$4.325(0.023)$} \\
\hline$b^{*}$ & $23.08 \pm 0.01$ & $20.29 \pm 0.05^{*}$ & $23.35 \pm 0.02$ & $15.75 \pm 0.04^{*}$ & $22.88 \pm 0.02$ & $19.45 \pm 0.03^{*}$ & $23.11 \pm 0.01$ & $20.94 \pm 0.03^{*}$ \\
\hline $\begin{array}{l}\text { Improvement } \\
\text { rates (\%) }\end{array}$ & \multicolumn{2}{|c|}{12.1} & \multicolumn{2}{|c|}{32.4} & \multicolumn{2}{|c|}{15.0} & \multicolumn{2}{|c|}{9.4} \\
\hline$t(p)$ & \multicolumn{8}{|c|}{$3.255(0.047)$} \\
\hline
\end{tabular}

$L^{*}$ values mean effectiveness in lightness, $a^{*}$ values mean effectiveness in covering redness, and $b^{*}$ values effectiveness in covering yellowness. Data are presented mean \pm standard deviation except for improvement rates and $t$ values.

${ }^{*} p<0.05,{ }^{* *} p<0.01$. 
Table 4. $L^{*} a^{*} b^{*}$ values and improvement rates of foreign-made products

\begin{tabular}{|c|c|c|c|c|c|c|c|c|}
\hline & \multicolumn{2}{|c|}{$\mathrm{F} \# 1$} & \multicolumn{2}{|c|}{$\mathrm{F} \# 2$} & \multicolumn{2}{|c|}{$\mathrm{F} \# 3$} & \multicolumn{2}{|c|}{$\mathrm{F} \# 4$} \\
\hline & Before & After & Before & After & Before & After & Before & After \\
\hline$L^{*}$ & $58.35 \pm 0.01$ & $61.35 \pm 0.06^{*}$ & $58.05 \pm 0.01$ & $61.43 \pm 0.06^{*}$ & $58.72 \pm 0.01$ & $65.53 \pm 0.06^{*}$ & $58.25 \pm 0.02$ & $66.21 \pm 0.06^{*}$ \\
\hline $\begin{array}{l}\text { Improvement } \\
\text { rates }(\%)\end{array}$ & \multicolumn{2}{|c|}{5.1} & \multicolumn{2}{|c|}{5.8} & \multicolumn{2}{|c|}{11.6} & \multicolumn{2}{|c|}{13.7} \\
\hline$t(p)$ & \multicolumn{8}{|c|}{$-4.278(0.023)$} \\
\hline$a^{*}$ & $13.11 \pm 0.02$ & $9.46 \pm 0.06^{* *}$ & $13.06 \pm 0.01$ & $11.14 \pm 0.05^{* *}$ & $13.05 \pm 0.01$ & $9.62 \pm 0.03^{* *}$ & $13.16 \pm 0.01$ & $10.13 \pm 0.05^{* *}$ \\
\hline $\begin{array}{l}\text { Improvement } \\
\text { rates (\%) }\end{array}$ & \multicolumn{2}{|c|}{27.9} & \multicolumn{2}{|c|}{14.7} & \multicolumn{2}{|c|}{26.2} & \multicolumn{2}{|c|}{23.0} \\
\hline$t(p)$ & \multicolumn{8}{|c|}{$7.821(0.004)$} \\
\hline$b^{*}$ & $23.36 \pm 0.01$ & $15.68 \pm 0.05^{*}$ & $23.44 \pm 0.02$ & $19.72 \pm 0.04^{*}$ & $23.36 \pm 0.02$ & $11.38 \pm 0.06^{*}$ & $23.60 \pm 0.01$ & $16.71 \pm 0.05^{*}$ \\
\hline $\begin{array}{l}\text { Improvement } \\
\text { rates }(\%)\end{array}$ & \multicolumn{2}{|c|}{32.9} & \multicolumn{2}{|c|}{15.9} & \multicolumn{2}{|c|}{51.3} & \multicolumn{2}{|c|}{29.2} \\
\hline$t(p)$ & \multicolumn{8}{|c|}{$4.447(0.021)$} \\
\hline
\end{tabular}

$L^{*}$ values mean effectiveness in lightness, $a^{*}$ values mean effectiveness in covering redness, and $b^{*}$ values effectiveness in covering yellowness. Data are presented mean \pm standard deviation except for improvement rates and $t$ values.

${ }^{*} p<0.05,{ }^{* *} p<0.01$.

Table 5. Comparison of $L^{*}, a^{*}, b^{*}$ values

\begin{tabular}{|c|c|c|c|c|}
\hline & Category & Before & After & Improvement rate (\%) \\
\hline \multirow{2}{*}{$L^{*}$} & Korean products & $58.62 \pm 0.23$ & $72.37 \pm 3.13$ & 23.5 \\
\hline & Foreign-made products & $58.34 \pm 0.28$ & $63.63 \pm 2.60$ & 9.1 \\
\hline \multirow{2}{*}{$a^{*}$} & Korean products & $13.35 \pm 0.34$ & $9.72 \pm 1.56$ & 27.2 \\
\hline & Foreign-made products & $13.10 \pm 0.05$ & $10.09 \pm 0.76$ & 23.0 \\
\hline \multirow{2}{*}{$b^{*}$} & Korean products & $23.11 \pm 0.19$ & $19.12 \pm 2.30$ & 17.3 \\
\hline & Foreign-made products & $23.44 \pm 0.11$ & $15.87 \pm 3.45$ & 32.3 \\
\hline
\end{tabular}

Data are presented mean \pm standard deviation except for improvement rates.

untreated Bioskin plate $(p=0.023)$. The improvement rates of $\mathrm{a}^{*}$ values were $27.9 \%$ for $\mathrm{F} \# 1,14.7 \%$ for $\mathrm{F} \# 2$, $26.2 \%$ for $\mathrm{F} \# 3$, and $23.0 \%$ for $\mathrm{F} \# 4$. The $\mathrm{a}^{*}$ values were all significantly higher than those of the untreated Bioskin plate $(p=0.004)$. The improvement rates of $b^{*}$ values were $32.9 \%$ for $\mathrm{F} \# 1$, $15.9 \%$ for $\mathrm{F} \# 2$, $51.3 \%$ for $\mathrm{F} \# 3$, and $29.2 \%$ for $\mathrm{F} \# 4$. The $\mathrm{b}^{*}$ values were all significantly higher than those of the untreated Bioskin plate ( $p=0.021$; Table 4$)$.

\section{Comparison of effectiveness in lightness}

The averages of $\mathrm{L}^{*}$ values were calculated in order to compare improvement rates between Korean and foreignmade products. Korean products measured 58.62 \pm 0.23 for before and $72.37 \pm 3.13$ for after, and the improvement rate was $23.5 \%$, although foreign-made products measured 58.34 \pm 0.28 for before and 63.63 \pm 2.60 for after, and the improvement rate was $9.1 \%$ (Table 5).

\section{Comparison of effectiveness in covering redness}

The average of $\mathrm{a}^{*}$ values was calculated in order to compare improvement rates between Korean and foreignmade products. Korean products measured 13.35 \pm 0.34 for before, and $9.72 \pm 1.56$ for after, and the improvement rate was $27.2 \%$, although foreign-made products measured $13.10 \pm 0.05$ for before and 10.09 \pm 0.76 for after, and the improvement rate was $23.0 \%$ (Table 5 ). 


\section{Comparison of effectiveness in covering yellowness}

The average of $b^{*}$ values was calculated in order to compare improvement rates between Korean and foreignmade products. Korean products measured 23.11 \pm 0.19 for before and 19.12 \pm 2.30 for after, and the improvement rate was $17.3 \%$, although foreign-made products measured 23.44 \pm 0.11 for before and 15.87 \pm 3.45 for after, and the improvement rate was $32.3 \%$ (Table 5).

\section{Conclusion}

$\mathrm{L}^{*} \mathrm{a}^{*} \mathrm{~b}^{*}$ values for Korean and foreign-made BB cream products were determined and compared using Bioskin plates. When comparing the $\mathrm{L}^{*}$ values, effectiveness in lightness, the improvement rate of Korean and foreignmade products were 23.5 and $9.1 \%$, respectively. This result suggests that Korean products better reflect the Korean consumers' preference for toning up. The imported products featured a transparent and natural color development. When comparing the effectiveness in covering redness, as measured by the a* value, the improvement rate of Korean products was higher than that of the foreign-made products $(27.2 \%$ versus $23.0 \%)$. This result indicates that the Korean products were designed to neutralize skin redness and develop a green color when applied. This is analogous to the use of greenish makeup base products to cover the redness of skin troubled by acne. When comparing the $b^{*}$ values, effectiveness in covering yellowness, the improvement rates of the Korean and foreign-made products were 17.3 and $32.3 \%$, respectively, indicating that the performance of the Korean products could be as low as 50\% of that of imported products. Although the imported products used in this study were released into the domestic market targeting Korean consumers, they were produced by European manufacturers. Traditionally, European companies have focused on the needs of people with whiter skin than Asians; therefore, the imported products might be formulated to mask yellow complexions as much as possible and develop bluish tones.

This work is part of the In Jung's Ph.D. thesis at the Konkuk University, Seoul, Korea.

\section{References}

Fabricant SM, Gould SJ. Women's makeup careers: an interpretive study of color cosmetic use and "face value". Psychology \& Marketing, 10: 531-548, 1993.

Kim H, Choi Y. Comparative study on changes in skin condition according to peeling care techniques. Asian Journal of Beauty and Cosmetology, 16: 82-92, 2018.

Kim KN, Jeon SH, Sim MK, Choi KH, Choi YJ, Han SH. A study on make-up products providing the effects of soothing and erythema improvement after dermatological surgery. Journal of the Society of Cosmetic Scientists of Korea, 37: 297-301, 2011.

Kim J, Park IK. Female sex pheromone components of the box tree pyralid, Glyphodes perspectalis, in Korea: field test and development of film-type lure. Journal of AsiaPacific Entomology, 16: 473-477, 2013.

Kim JD, Kim SJ, Kim HS, Park KH, Lee WS, Jin JE. New cosmetic science. Dong Hwa Technology Publishing (2nd ed.), Paju, pp478-487, 2004. (Takeo M. 2000).

Kim MY, Chung JY. Make-up due to interest on the characteristics of BB cream consumption survey. Journal of the Korean Society of Design Culture, 17: 50-62, 2011.

Kowner R. When ideals are too "far off": physical self-ideal discrepancy and body dissatisfaction in Japan. Genetic, Social, and General Psychology Monographs, 130: 333361, 2004.

Lee SK. Makeup color expressions depending upon skin types and defects: focusing on nevus. Asian Journal of Beauty and Cosmetology, 3: 81-89, 2005.

Nakamura N. Optical measurements of skin properties and their application to makeup products. Journal of Society of Cosmetic Chemists of Japan, 32: 233-239, 1998.

Nonomura Y, Yamaguchi A. Stribeck curves for water and thickener aqueous solutions on striped rough surfaces. Chemistry Letters, 45: 206-208, 2016.

Park YE, Chin CH. Analysis of B.B cream used condition. Asian Journal of Beauty and Cosmetology, 8: 63-74, 2010.

Sato N, Murata A, Fujie T, Takeoka S. Stretchable, adhesive and ultra-conformable elastomer thin films. Soft Matter, 12: 9202-9209, 2016.

Sahay S, Piran N. Skin-color preferences and body satisfaction among South Asian-Canadian and European-Canadian 
female university students. The Journal of Social Psychology, 137: 161-171, 1997.

Shimizu R, Nonomura Y. Preparation of artificial skin that mimics human skin surface and mechanical properties. Journal of Oleo Science, 67: 47-54, 2018.

Weatherall IL, Coombs BD. Skin color measurements in terms of CIELAB color space values. Journal of Investigative Dermatology, 99: 468-473, 1992.

Yun IS, Lee WJ, Rah DK, Kim YO, Park BY. Skin color analysis using a spectrophotometer in Asians. Skin Research and Technology, 16: 311-315, 2010.

Zilhão J, Angelucci DE, Badal-García E, d'Errico F, Daniel F, Dayet L, Douka K, Higham TF, Martínez-Sánchez MJ, Montes-Bernárdez R, et al. Symbolic use of marine shells and mineral pigments by Iberian Neandertals. Proceedings of the National Academy of Sciences of the United States of America, 107: 1023-8, 2010. 


\section{국문초록}

\section{국가별 베이스 메이크업 제품의 색상 비교}

정인 ${ }^{1,2}$, 안인숙 ${ }^{2}$, 안성관 ${ }^{3 *}$

${ }^{1}$ 건국대학교 생물공학과, 서울, 한국

${ }^{2}$ 한국피부과학연구원, 서울, 한국

${ }^{3}$ 건국대학교 화장품공학과, 서울, 한국

목적: 국내에 출시된 한국산 및 수입산 베이스 메이크업 제품의 색상을 비교함으로써 커버력에 대한 효과를 측정하고자 한다. 방 법: $\mathrm{L}^{*} \mathrm{a}^{*} \mathrm{~b}^{*}$ 값의 비교를 위해 Bioskin plate에서 분광광도계를 이용하여 전후 데이터를 측정하고, 각 국가 별 제품의 평균 수치와 표 준 편차를 계산하였으며, 통계로 검증하였다. 결과: 한국산 제품의 밝기는 $23.5 \%$ 로 수입산 제품인 $9.1 \%$ 에 비해 높은 것으로 나타 났으며, 붉은기 커버력도 한국산 제품이 $27.2 \%$ 로 수입산 제품인 $23.0 \%$ 에 비해 높은 것으로 나타났으나, 노란기 커버력은 한국산 제품이 $17.3 \%$ 로 수입산 제품인 $32.3 \%$ 에 비해 낮은 것으로 나타났다. 결론: 한국산 제품은 한국 여성의 선호도를 반영한 밝기와 붉 은기 커버력에서 강점을 보였고, 수입산 제품은 상대적으로 더 내추럴하게 발색되는 서양인의 선호도가 반영된 것으로 사료된다.

핵심어: 피부색, 얼굴, 한국여성, 베이스메이크업, 비비크림

\section{참고문헌}

김경남, 전상훈, 심인경, 최경호, 최영진, 한상훈. 피부과 시술 후 진정 및 홍반 개선 효과를 제공하는 메이크업 제품에 대 한 연구. 대한화장품학회지, 37: 297-301, 2011.

김미영, 정재윤. 메이크업관심도에 따른 비비크림 소비특성에 관한 조사. 한국디자인문화학회지, 17: 50-62, 2011.

김주덕, 김상진, 김한식, 박경환, 이화순, 진종언. 신화장품학 제2판. 동화기술, 파주, pp 478-488, 2004. (미츠이 다케 오. 2000).

김희숙, 최영희. 박피 방법에 따른 피부 상태 변화에 관한 비교 연구. 아시안뷰티화장품학술지, 16: 82-92, 2018. 박영은, 진정화. 비비크림의 사용현황 조사. 아시안뷰티화장품학술지, 8: 63-74, 2010.

이수경. 피부유형과 결점에 따른 메이크업색채표현: 모반을 중심으로. 아시안뷰티화장품학술지, 3: 81-89, 2005. 


\section{中文摘要}

\section{韩国和国外基础彩妆产品的颜色比较}

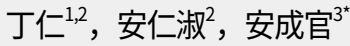

建国大学生物工学科, 首尔, 韩国

2韩国皮肤科学研究院, 首尔, 韩国

建国大学化妆品工学科, 首尔, 韩国

目的：比较韩国推出的韩国产和进口基础彩妆产品的颜色，测定其覆盖效果。方法：为了比较 $L^{*} a^{*} b^{*}$ 值，使用分 光光度计在Bioskin plate上测量数据, 计算各国家产品的平均值和标准偏差, 并用统计验证。结果: 韩国产品 的亮度改善率高于国外产品（23.5\%对9.1\%），韩国产品的红色覆盖改善率也较高（27.2\%对23.0\%），但韩 国产品的黄色覆盖改善率低于国外产品（17.3\%和32.3\%）。结论：韩国产品更能体现韩国女性的喜好，在亮 度和红色覆盖方面占优势, 进口产品具有透明和自然的颜色发展, 更能体现西洋人的喜好。

关键词: 肤色，脸，韩国女性，底妆，BB霜 